\title{
GROUNDING THE DIRECTIONS OF CHANGES IN THE CYCLE OF MANAGEMENT CHANGES AT THE ENTERPRISE
}

\begin{abstract}
Г.А. Дорошук. Обгрунтування напрямків змін в циклі управління змінами на підприємстві. Актуальність вибору й обгрунтування напрямків змін обумовлена необхідністю адаптації підприємства до мінливого зовнішнього середовища і підвищення його конкурентоспроможності. В роботі на основі підходів до управління змінами запропоновано цикл управління змінами на підприємстві, який складається 3 шести етапів, центральним 3 яких $\epsilon$ етап проектування змін. Аналіз методів управління змінами й змістових моделей управління змінами дозволив обгрунтувати такі напрямки змін: структура, стратегія і місія, персонал і навички, культура і стиль, лідер змін, система винагород, процеси і технології. Для кожного з напрямків розроблено якісні і кількісні симптоми необхідності змін. Отримані теоретичні результати в подальшому можуть бути використані як основа для розробки системи інструментів реалізації кожного напрямку і формування системи показників результативності змін.

Ключові слова: зміни, управління змінами, підходи до управління змінами, методи управління змінами, цикл управління змінами, напрямки змін, кількісні і якісні симптоми необхідності змін.

G.A. Doroshuk. Grounding the directions of changes in the cycle of management changes at the enterprise. Actuality of choosing and grounding the directions of changes is caused by necessity of adaptation the enterprise to changing external environment and increasing enterprise's competitiveness. In paper on basis of approaches to change management the cycle of change management are proposed, it consists of six stages, the main of them is design of changes. By analysis of change management methods and content models of changes management the directions of changes are grounded, they are structure and management system, strategy and mission, staff and skills, culture and values, reward system, leader of change processes and technologies. For every direction quantitative and qualitative symptoms that indicate a necessity of change are worked out. Further the theoretical results can be used as a basis for the creating tools for implementing each of the proposed areas of change and forming of the system of performance indicators for changes.

Keywords: changes, change management, approaches in change management, methods of change management, cycle of change management, directions of changes, quantitative and qualitative symptoms that indicate a necessity of change.

Introduction. The modern state and subsequent development of economy in Ukraine is predetermined by the necessity of search the ways of creation the competitive industrial complex. One of the major pre-conditions of acceleration the development of industrial enterprises in these conditions is conforming the requirements of environment. Usually, external and internal factors force an enterprise to change the internal environment in accordance with the requirements of contemporaneity. Un-
\end{abstract}

DOI 10.15276/opu.2.46.2015.30

(C) 2015 The Authors. This is an open access article under the CC BY license (http://creativecommons.org/licenses/by/4.0/). 
stable conditions of operating demand the realization of changes and introduction of innovations. At this time the question of effective and "painless" introduction of changes appears enterprises as condition further existence of enterprises in competitive environment. For this reason the study of organizational development and changes acquire the special actuality.

Literature review. Issues of change management investigated the such foreign scientists as I. Adizes, I. Ansoff, L. Greiner, J. Kotter, W. Kruger, K. Lewin, M. Mescon, G. Shirokova, O. Vikhanskii and Ukrainian authors: S.I. Bay, D.K. Voronkov, I.I. Gribik, T. Kuzhda, S.R. Stetsiv and others.

All models in change management are divided on two groups: process models and content models. The first of process model was offered by K. Lewin. This model consists of three stages:

- "unfreeze" is the first stage of change that involves preparing the organization to accept that change is necessity of change, which means break down the existing status quo before you can build up a new way of operating;

- the change stage is where people begin to resolve their uncertainty and look for new ways to do things. People start to believe and act in ways that support the new direction;

- "refreeze" means making sure that the changes are used all the time; and that they are incorporated into everyday business [1].

Larri Greiner's model consists of six stages: factors;

- Pressure of external factors and determination of changes necessity by dynamics of internal

— Invitation the external consultant — agent of changes — and search the leader of changes in organization;

- Collection the information and specification about problems;

- Experimental introduction of changes and their correction for the increasing of efficiency;

- Supporting change and motivation [2].

Kotter's 8-Step Change Model includes:

- Creating urgency around the need for change sparks the initial motivation to get things moving;

- Forming a powerful coalition;

- Creating a vision for change that helps everyone understand what is the changes;

- Communicating the vision;

- Removing obstacles includes changes in structure;

- Creating short-term wins should give the company a taste of victory early in the change process;

- Building on the change;

- Anchor the changes in corporate culture [3].

Also interesting is a pattern of organic growth [2]. Its first step is determination of vision, mission, aims and values, in the second step, namely changes are possible due to the so-called experiments or "ice-breaking" events.

Process model helps to understand the process of change, which changes not only the management system but also organizational and individual behavior. In whole, these models are produced and used by sociologists, researches of organization behavior and psychology, business consultants.

These models are useful, repeatedly approved, they've got practical meaningfulness, but have some in elaborateness from the side of management of change process. Their substantial failing is insufficient definiteness of possible directions of changes. In practice this failing is compensated by content models which allow to select directions - "fields" of changes exactly. The content models are close to the strategic management. But they also do not represent the chart of complete managerial cycle in relation to realization of changes and are not enough to specify managerial instruments realization of changes on every stage.

An attempts to solve these failings were done in works of S.R. Steciva [4] and T. Kuzhdi [5]. Both authors view the process of changes, as aggregates of functions: planning, organizing, motivating and controlling. In T. Kuzhdi's paper there is considered, but not grounded such directions of changes on the stage of their planning: changes in a production program change in technique and technology, 
change in the staff, change in logistical support, change in cost, income and profitability, changes in the financial providing, changes in social development.

Practical use of the aforementioned models by top-management requires a clear sequencing in change management, which should include the stages of management, the content and managerial instruments of the stages and the results.

Aim of the Research. The analysis all above does actual the search directions of change in the cycle of change management on the enterprise. In this paper, we develop the cycle of change management and determine the directions of change.

The aim is to select and ground directions of change in the cycle of change management in the enterprise.

To achieve this aim we need to solve the following tasks:

- identify the cycle of change management;

- review the methods of change management;

- ground the choice of direction of changes;

- develop the quantitative and qualitative symptoms of necessity the direction of change.

Main Body. Cycle of change management is a set of change management process: obtaining information, the decision to change, change implementation and monitoring of the implementation of changes. The cycle of change management can be seen as part of the process approach as a series cycle of decision-making. This is possible due to the fact that most changes are intended:

- or to development, these are planned changes, that are made to realize the strategy of development, in which the organization tries to predict their actions with regard to future events. For this the trends of the environment, its opportunities and threats, as well as the strengths and weaknesses of the organization should be studied. The purpose of these plans is to prepare the organization for possible changes in the environment, to resist the adverse effects of random factors;

- or to removal the problems, these are natural (reactive) changes, unexpected response organizations to unforeseen circumstances as they arise. Therefore, as a rule, they are made under time pressure, there is not enough thought out and not effectively adapt to the environment. Often after such changes need to manage the change increases.

So identification the directions of changes is a managerial decision, directed either to develop or to eliminate problems.

There are more than ten approaches that use in change management [6]. To achieve the aim of this paper as well as process approaches situational, contextual, competence will be used:

- situational approach that uses of the most appropriate to situation management tools or direction changes;

- contextual approach, which involves an analysis of the external environment and internal factors. For change management, this means searching symptoms that indicate the need for change in any element of external environment and searching for "fields" of change - elements internal environment that need to be changed first;

- competence approach: for managing the changes an agent of change - external consultant need to be attracted, changes require a leader of change who forms a team of change [7].

The cycle of change management is shown in Table 1.

The main stage in a cycle of change management is "design changes" under influence of external and internal environment.

The choice the direction changes of is closely linked to the demands of external environment. There are five main driving forces: competition, economical and political forces, globalization, demographic and social, ethical.

Competitive forces require the actions that will allow the company to go to the level and beat the competitors in efficiency of activity (e.g., cost), innovations, product quality and reliability.

Economic and political forces constantly affect to market conditions and the rules by which companies produce and sell their products, services, and force them to reconsider their positions in the production and sales activities. 
The forces of globalization influence to the company on the foreign markets with different languages, culture and business practices.

Demographic and social forces aim at increasing diversity among staff, establishment and effective management of the system of remuneration that takes into account the needs and expectations of employees. On the market, the company must be prepared to adapt their products and services for unique requirements of a particular demographic group defined by customers.

The ethical forces cover social responsibility of business practices and encourage the honest and ethical actions.

There are three main groups of methods in change management:

- Methods focused on the structure and strategy. Change programs covering the entire organization, often associated with changes in the organizational structure and strategy and, consequently, in the culture. Changes in the structure include changes in the positions or roles and reorientation of relations between them, and between workgroups and departments. Strategy is a plan of action in order to achieve organizational goals. In other words, it is about changing the entire set of actions and may lead to revision of the same goals;

- Methods focused on people and culture and most are designed for the active involvement and participation in the majority of employees. If they are successful, these methods improve individual and group processes in decision-making, communication, behavior, leadership and so on. Changes in organizational culture influence to values, expectations, disposition and behavior of workers;

- Methods focused on the task and technology pay the main attention to technological processes, business-processes, management processes that are used to perform certain tasks.

Table 1

The cycle of change management at the enterprise

\begin{tabular}{|c|c|c|}
\hline Name of stage & Contents stage & Results \\
\hline Preparatory & $\begin{array}{l}\text { Selecting an object of changes } \\
\text { Choosing an agent of changes } \\
\text { Selection a team of changes } \\
\text { Description of joint changes in expectations }\end{array}$ & $\begin{array}{l}\text { The object of changes } \\
\text { Characteristics of change expecta- } \\
\text { tions }\end{array}$ \\
\hline $\begin{array}{l}\text { Information- } \\
\text { gathering stage }\end{array}$ & $\begin{array}{l}\text { Searching the problems } \\
\text { Setting objectives to change } \\
\text { Collecting of information } \\
\text { The study of the factors that led to the need for } \\
\text { change } \\
\text { Description of the symptoms of the necessity for } \\
\text { change }\end{array}$ & $\begin{array}{l}\text { Vision } \\
\text { Mission } \\
\text { Values } \\
\text { Objectives change } \\
\text { Joint changes in expectations } \\
\text { Information about the external and } \\
\text { internal environment }\end{array}$ \\
\hline Design of changes & $\begin{array}{l}\text { Designing the direction of change } \\
\text { Evaluation of personnel readiness for change } \\
\text { Evaluation of resistance }\end{array}$ & $\begin{array}{l}\text { Directions of change } \\
\text { System of performance-indicators } \\
\text { changes } \\
\text { Personnel readiness to change } \\
\text { Experiments }\end{array}$ \\
\hline $\begin{array}{l}\text { Implementation of } \\
\text { changes }\end{array}$ & $\begin{array}{l}\text { Selection of the optimal implementation of } \\
\text { changes } \\
\text { Implementation of the plan of changes } \\
\text { Overcoming resistance } \\
\text { Staff training }\end{array}$ & $\begin{array}{l}\text { Experiments } \\
\text { Splits ice events }\end{array}$ \\
\hline $\begin{array}{l}\text { Assessment and } \\
\text { stabilization results }\end{array}$ & $\begin{array}{l}\text { Evaluation of success } \\
\text { Assess the need for further action } \\
\text { Identify opportunities and priorities for further } \\
\text { development } \\
\text { Staff training }\end{array}$ & $\begin{array}{l}\text { The results of changes } \\
\text { Priorities of development } \\
\text { Staff training }\end{array}$ \\
\hline $\begin{array}{l}\text { Closing the project } \\
\text { changes }\end{array}$ & $\begin{array}{l}\text { Collapsing relations "change agent consultants" } \\
\text { Monitoring the achieved results }\end{array}$ & $\begin{array}{l}\text { The results of changes } \\
\text { The functioning of the organiza- } \\
\text { tion after the change }\end{array}$ \\
\hline
\end{tabular}


There are a lot of content models of change management, whose task is to implement the above methods. Each of them advises management to work on certain objects of change - structure, strategy and objectives, staff, system of rewards, technology, culture and so on. Table 2 shows the comparative characteristics of several popular content models: model 7S, McKinsey's model, Weisbord's model, star model by Galbraith, Kotter's model and model by Burke-Litwin.

Common characteristic of these all models is that they consider changes for an enterprise as for single system, as a mechanism. Indeed, at first glance, small changes in one of the areas of management can affect the activity of the others.

Table 2

The characteristics of the models of change management

\begin{tabular}{l|l|c|c|c|c|c|c}
\hline $\begin{array}{c}\text { Main groups } \\
\text { of methods in } \\
\text { change } \\
\text { management }\end{array}$ & $\begin{array}{c}\text { The object of } \\
\text { changes }\end{array}$ & $\begin{array}{c}\text { Model } \\
7 \mathrm{~S}\end{array}$ & $\begin{array}{c}\text { Model } \\
\text { McKinsey }\end{array}$ & $\begin{array}{c}\text { Weisbord's } \\
\text { model }\end{array}$ & $\begin{array}{c}\text { Galbraith's } \\
\text { Star model }\end{array}$ & $\begin{array}{c}\text { Kotter's } \\
\text { model }\end{array}$ & $\begin{array}{c}\text { Burke- } \\
\text { Litwin's } \\
\text { model }\end{array}$ \\
\hline $\begin{array}{l}\text { Methods fo- } \\
\text { cused on the } \\
\text { structure and } \\
\text { strategy }\end{array}$ & $\begin{array}{l}\text { Structure and } \\
\text { system }\end{array}$ & + & + & + & + & - & - \\
\cline { 2 - 9 } & $\begin{array}{l}\text { Strategy and } \\
\text { mission }\end{array}$ & + & + & + & + & + & + \\
\hline \multirow{2}{*}{$\begin{array}{l}\text { Methods, ori- } \\
\text { ented on peo- } \\
\text { ple and cul- } \\
\text { ture }\end{array}$} & Staff and skills & + & + & + & + & + & - \\
\cline { 2 - 9 } & $\begin{array}{l}\text { Culture, values } \\
\text { and style }\end{array}$ & + & - & + & + & + & - \\
\cline { 2 - 9 } \\
\cline { 2 - 9 }
\end{tabular}

Results. Based on the analysis of these change management models, some directions of change can be concluded: structure and management system, strategy and mission, staff and skills, culture and values, reward system, leader of change, processes and technologies. With this a list of the directions of change can be made. It can look like this:

1. "Structure and management system" include change the organizational structure, staffing, formation of new departments, the elimination of structural units, strengthening relations between the structural elements, automation of workflow.

2. "Strategy and mission" include change in vision and mission of the organization, the strategy of development, in policy of organization, change of direction of development.

3. "Skills and staff" include training and retraining of personnel, changes in staffing, automation of labor, hire and fire.

4. "Culture, values and style" include a change of corporate culture, establishment of corporate events, introducing uniforms, changing in management style, changing in decision-making.

5. "The leader of change" is usually a stronger personality than a regular leader, as he not only leads the team, but based on the title, leading the team to a new desired state, changing the core values, goals, norms of behavior in organizations [7].

6. "The reward system" include change the size and order bonuses, material compensation for his significant contribution to the development of the company, changing forms and payment system, the introduction or eradication of moral compensation. 
7. "Processes" include redesign of managerial processes and procedures with using the advanced information technologies.

8. "Technologies" include replacement of equipment, changes in manufacturing processes, automation of production, modernization of production, introduction of innovations.

To ground the choice the direction of change symptoms that indicate a necessity for change are proposed. Table 3 shows the quantitative and qualitative symptoms that may indicate a necessity for change.

Table 3

Quantitative and qualitative symptoms that indicate a necessity for change

\begin{tabular}{l|l|l}
\hline The object of changes & \multicolumn{1}{|c}{ Quantitative symptoms } & \multicolumn{1}{c}{ Quality symptoms } \\
$\begin{array}{l}\text { Structure and } \\
\text { management system }\end{array}$ & $\begin{array}{l}\text { Significant managerial cost, low per- } \\
\text { formance efficiency and reliability } \\
\text { management }\end{array}$ & $\begin{array}{l}\text { Increasing complexity of decision- } \\
\text { making, bureaucracy }\end{array}$ \\
\hline Strategy and mission & $\begin{array}{l}\text { Decrease in market share, decrease } \\
\text { sales, decrease the market value of the } \\
\text { shares }\end{array}$ & $\begin{array}{l}\text { Falling popularity of products, reducing } \\
\text { the recognizability of the brand, the } \\
\text { change in ownership }\end{array}$ \\
\hline Staff and skills & $\begin{array}{l}\text { Increasing staff turnover, low produc- } \\
\text { tivity }\end{array}$ & $\begin{array}{l}\text { Lack of educated personnel, lack of } \\
\text { qualified staff, lack of competence }\end{array}$ \\
\hline Culture and style & $\begin{array}{l}\text { Increasing the number of conflicts, the } \\
\text { fall in productivity, availability of } \\
\text { complaints from consumers }\end{array}$ & $\begin{array}{l}\text { Inflexibility management, outdated } \\
\text { views on business management, tensions } \\
\text { between staff }\end{array}$ \\
\hline Reader of changes & $\begin{array}{l}\text { Decreasing effectiveness the enterprise, } \\
\text { reduce the cost of innovation }\end{array}$ & $\begin{array}{l}\text { The lack of vision among staff, de- } \\
\text { creased motivation }\end{array}$ \\
\hline Processes & $\begin{array}{l}\text { Arrears of wage, reducing payroll, } \\
\text { unjustified increasing in payroll, }\end{array}$ & $\begin{array}{l}\text { Dissatisfaction with the current system } \\
\text { rewards employees, low motivation }\end{array}$ \\
\hline Technologies & Rising costs, decline in quality & $\begin{array}{l}\text { Uncertainty of key business-processes, } \\
\text { inefficient processes of communication } \\
\text { and decision-making }\end{array}$ \\
\hline
\end{tabular}

Conclusions. Using process, situational, contextual, competence approaches allowed to form the cycle of change management at the enterprise, which consists of six stages: preparatory, informationgathering stage, design of changes, implementation of changes, assessment and stabilization results, closing the project of changes. The most interesting the stage of design changes is represented. For choosing the directions of changes three main methods and content models of change management were analyzed. It allowed to ground such directions of change: structure and management system, strategy and mission, staff and skills, culture, values and style, reward system, leader of change, processes and technologies. For every directions the quantitative and qualitative symptoms that indicate a necessity of change were worked out.

Prospects of research in this direction is to create tools for implementing each of the proposed areas of change and the formation of the system of performance indicators for changes.

\section{Література}

1. Smith, M.K. Kurt Lewin: groups, experiential learning and action research [Електронний pecypc] / M.K. Smith // The Encyclopedia of Informal Education. — 2001. — Режим доступу: http://www.infed.org/ thinkers/et-lewin.htm (Дата звернення: 22.11.2014).

2. Myers, P. Organizational change: Perspectives on theory and practice / P. Myers, S. Hulks, L. Wiggins. Oxford: Oxford University Press, 2012. — 384 p. 
3. Kotter, J.P. Leading change: Why transformation efforts fail / J.P. Kotter // Harvard Business Review. 2007. - Vol. 85, Issue 1. - PP. 96 - 103.

4. Стеців, С.Р. Сутність та етапи управління змінами на підприємстві / С.Р. Стеців // Вісник Національного університету «Львівська політехніка». Менеджмент та підприємництво в Україні: етапи становлення і проблеми розвитку. — 2011. — № 714. — С. $155-161$.

5. Кужда, Т. Етапи успішного управління організаційними змінами на підприємстві / Т. Кужда // Галицький економічний вісник. - 2013. - № 2(41). - С. $66-72$.

6. Воронков, Д.К. Інтеграція підходів до управління змінами на підприємстві / Д.К. Воронков // Економіка. Менеджмент. Підприємництво. — 2010. — № 22(II). - С. 152 - 158.

7. Дорошук, Г.А. Кадрове забезпечення управління змінами [Електронний ресурс] / Г.А. Дорошук, Г.О. Савченко // Економіка: реалії часу. Науковий журнал. - 2014. — № 3(13). - С. 50 - 56. Режим доступу до журн.: http://economics.opu.ua/files/archive/2014/No3/50-56.pdf (Дата звернення: 22.11.2014).

\section{References}

1. Smith, M.K. (2001). Kurt Lewin: groups, experiential learning and action research. The Encyclopedia of Informal Education. Retrieved from http://www.infed.org/thinkers/et-lewin.htm

2. Myers, P., Hulks, S. and Wiggins, L. (2012). Organizational Change: Perspectives on Theory and Practice. Oxford: Oxford University Press.

3. Kotter, J.P. (2007). Leading change: Why transformation efforts fail. Harvard Business Review, 85(1), 96-103. (Original work published 1995)

4. Stetsiv, S. (2011). The essence and stages of change management at the enterprise. Herald of National University "Lvivska Politechnika": Management and Entrepreneurship in Ukraine - Formation Stages and Problems of Development, 714, 155-161.

5. Kuzhda, T. (2013). Steps for successful organizational change management at the enterprise. Galician Economic Bulletin, 2, 66-72.

6. Voronkov, D. (2010). Integration of approaches to management of changes of enterprise. Economy. Management. Entrepreneurship, 22(II), 152-158.

7. Doroshuk, G.A. and Savchenko, G.O. (2014). Staffing management changes. Economics: Time Realities, 3. Retrieved from http://economics.opu.ua/files/archive/2014/No3/50-56.pdf 